\title{
EARLY BIOCHEMICAL DEFECTS CAUSED BY DIETARY TRACE ELEMENT DEFICIENCIES
}

\author{
J. K. CHESTERS AND J.R. ARTHUR \\ Rowett Research Institute, Bucksburn, Aberdeen AB2 9SB
}

\section{CONTENTS}

INTRODUCTION
$\begin{aligned} & \text { ENZYMES } \\ & \text { ENERGY SUPPLY AND CELL METABOLISM }\end{aligned}$
OXIDATIVE STRESS

\section{INTRODUCTION}

Many of the early studies of the metabolism of the trace elements were aimed at providing methods of assessing the adequacy of intake of individual elements. This may be achieved either by estimating body reserves of the elements or by determining whether their essential functions are being adequately maintained. Newly-evolving methods of assessing reserves include, for zinc, studies of metallothionein concentrations in blood or urine (Bremner et al. 1987) and, for iron, immunoassay of plasma ferritin levels (Peter \& Wang, 1981). However, since trace element reserves are only of value in ensuring adequate functional capacity, methods based on the former approach must be calibrated against functional criteria. Furthermore, it has become increasingly evident that adverse biochemical changes can occur before diagnostic signs of trace element deficiencies are apparent. Such defects include reduced candidacidal activity of neutrophils from copper and selenium-deficient rats, mice and cattle (Boyne \& Arthur, 1981, 1986a), degenerative changes in pancreas of cattle with low $\mathrm{Cu}$ intakes (Fell et al. 1985) and restricted growth of many species when $\mathrm{Zn}$ intakes are inadequate. Increasingly, therefore, investigations will concentrate on the functional roles of the trace elements with a view to being able to identify subclinical deficiencies. In the past, investigators frequently studied the multiple roles of individual elements, but to understand their significance each must be seen as an integral part of a particular metabolic pathway. For this reason, the present review will attempt to indicate how the trace elements function within an animal's overall metabolism.

The reference in the title to early defects relates to the time-course of onset of a deficiency and it should be recognized throughout that this may correspond to depletion for only a few days in the case of $\mathrm{Zn}$ but at the other extreme may extend with manganese deficiency into a second generation. 


\section{ENZYMES}

The nutritional requirements for trace elements have frequently been attributed to their function as essential components of a range of enzymes. The only clearly-defined functional role for $\mathrm{Se}$ in animals is as part of the active centre of glutathione peroxidase ( $E C$ 1.11.1.9; GSHPx). Because the activity of this enzyme responds rapidly to alterations in dietary Se intake, it provides probably one of the best links between the intake of a trace element and its functional adequacy (Hafeman et al. 1974). Recently, evidence has been obtained that the carbon skeleton of the selenocysteine moiety in this protein is derived from serine and the seleno-amino acid is uniquely coded for by the triplet TGA (Chambers et al. 1986; Sunde \& Evenson, 1987). This triplet normally acts as a stop codon and there will undoubtedly be much interest in what controls the interpretation of the codon during translation. Interestingly immunological evidence suggests that loss of GSHPx activity during the onset of Se deficiency is faster than loss of the protein (Knight \& Sunde, 1987). However, once the deficiency has become established, the activity of the enzyme seems to be directly related to the amount of peroxidase-protein present (Takahashi et al. 1986). Possibly there is a transient state accompanying a reduction in Se status during which enzyme activity is lost more rapidly than the protein is degraded.

Although many of the effects of Se deficiency can be attributed to loss of Se-containing GSHPx activity, some of the consequences of the deficiency may be due to hitherto unidentified functions for Se (Burk, 1983; Reiter \& Wendel, 1983, 1985; Hill et al. 1987; Arthur et al. $1988 \mathrm{~b}$ ). This has led to interest in the identification of several seleno-proteins to which no specific functions have as yet been assigned (Sunde, 1984; Combs \& Combs, 1986; Evenson \& Sunde, 1988). Probably the most-intensively studied of these non-GSHPx seleno-proteins is the 'P-protein' (molecular weight 75000-80000) found in plasma, liver and kidney (Burk \& Gregory, 1982; Motsenbocker \& Tappel, 1984). Recently, monoclonal antibodies to P-protein have been prepared and a radioimmunoassay used to quantify the effects of Se deficiency on levels of the protein in plasma (Yang et al. 1987). This protein may well have an important function since, on repletion of Se-deficient animals with Se, its concentration returns to normal before that of GSHPx.

Another newly-recognized consequence of Se deficiency is an elevation of the concentration of thyroxine (T4) and reduction in triiodothyronine (T3) in plasma in rats and cattle (Beckett et al. 1987; Arthur et al. 1988 a). This appears to stem from a reduced rate of conversion of $\mathrm{T} 4$ to the more-metabolically-active $\mathrm{T} 3$ due to lowered activity of the hepatic microsomal deiodinase (Beckett et al. 1987). Interestingly both a hypothyroid state and severe Se deficiency result in increased activities of a number of glutathione Stransferases (EC 2.5 1 1 18; GST) (Arias et al. 1976; Arthur et al. 1987). Since certain of the latter have peroxidase activities with organic hydroperoxides similar to that of GSHPx, it has been suggested that their activity is enhanced in Se deficiency to compensate for loss of GSHPx. However, investigation of the response of individual GST has now shown that their activities increase to comparable extents independently of their ability to act as peroxidases (Arthur et al. 1987). Furthermore, the increases in GST activity do not appear to be secondary to an induced hypothyroidism since these increases could be reversed by small doses of Se which did not ameliorate the defective T 4 metabolism (Reiter \& Wendel, 1984; Arthur et al. 1988 b).

$\mathrm{Zn}$ is recognized as a component of numerous enzymes, examples being found in each of the main classes (Vallee \& Galdes, 1984). However, although it seemed likely that the effects of $\mathrm{Zn}$ deficiency would be attributable to loss of a $\mathrm{Zn}$ metalloenzyme and some, for example, plasma alkaline phosphatase $(E C$ 3.1.3.1), and lactic dehydrogenase (EC 1.1.1.27) are reduced in activity sufficiently rapidly to be helpful in diagnosing the 


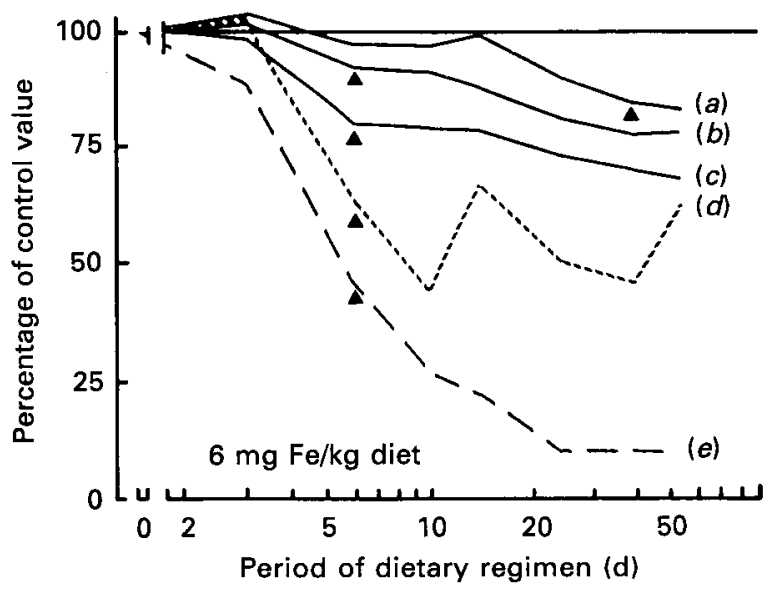

Fig. 1. Sequence of development of iron deficiency. (a) Muscle cytochrome $c$; $(b)$ packed cell volume; (c) cytochrome c; (d) transferrin saturation; (e) liver Fe. (A) The day on which differences between Fe-deficient and control groups first became significant $(P<0-05)$; thereafter the differences remained significant at all samplings.

deficiency in both animals and man (Kirchgessner \& Roth, 1975; Prasad, 1982), none have yet been implicated in the failure of growth caused by lack of $\mathrm{Zn}$. Illustrative of the situation is a reduction in angiotensin-converting enzyme (EC 3.4.15.1), a $\mathrm{Zn}$ dipeptidase, in Zn-deficient rats which nevertheless had normal concentrations of angiotensin II in their plasma (Reeves \& O'Dell, 1986). Similarly, the activity of fructose1, 6-bisphosphatase (EC 3.1.3.11) which contains twelve $\mathrm{Zn}$ per molecule and is a regulatory enzyme in gluconeogenesis, decreased by nearly $50 \%$ in the liver of rats within $1 \mathrm{~d}$ on a $\mathrm{Zn}$-deficient diet. It could also be restored to normal within $30 \mathrm{~min}$ of $\mathrm{Zn}$ supplementation but the plasma glucose levels of the $\mathrm{Zn}$-deficient animals were not affected (Cowen et al. 1986). In contrast, lowered plasma glucose values were observed in pups from dams reared on a $\mathrm{Mn}$-deficient diet and these were associated with decreased activities of phosphoenolpyruvate carboxykinase (EC 4.1.1.49), a Mn-enzyme also involved in gluconeogenesis (Baly et al. 1984). Thus the effects of trace element deficiencies on an animal's metabolic pathways depend not only on the presence of metalloenzymes but also on the extent to which these enzymes control the flux of metabolites through the pathways.

Loss of $\mathrm{Fe}$ as a component of haem in haemoglobin, myoglobin and cytochromes probably accounts for most of the biological effects of Fe deficiency (Beard et al. 1984; Dallman, 1986). Fig. 1 illustrates a time-course of depletion of haem-Fe in rats offered an Fe-deficient diet and shows that losses occurred before $\mathrm{Fe}$ reserves were exhausted (Dallman et al. 1982).

$\mathrm{Cu}$ is a component of several enzymes which may lose activity in $\mathrm{Cu}$ deficiency and lead to biochemical and metabolic changes. At least five such enzyme systems are recognized as having possible relevance to the occurrence of defects in $\mathrm{Cu}$ deficiency (see Prohaska \& Heller, 1982). Thus loss of cytochrome oxidase (EC 1.9.3.1) activity may affect mitochondrial metabolism, reduced superoxide dismutase $(E C$ 1.15.1.1) will affect cell antioxidant systems, catecholamine metabolism can be altered by decreased dopamine- $\beta$ hydroxylase $(E C 1.14 .17 .1)$, decreased lysyl oxidase activity may adversely influence collagen and elastin formation and loss of ferroxidase activity of caeruloplasmin (EC 1.16.3.1) may change Fe metabolism. Prohaska \& Heller (1982) concluded that the 
hypertrophy and abnormal functioning of hearts from $\mathrm{Cu}$-deficient rats could arise from changes in at least three of these enzyme systems, resulting in alterations in the elastic properties of muscle, cardiac catecholamine depletion and defective energy metabolism, but the relative importance of each was not clear. Some enzyme changes in $\mathrm{Cu}$ deficiency and also cardiac hypertrophy are more severe in rats when a large proportion of dietary carbohydrate consists of fructose rather than glucose or starch (Reiser et al. 1983; Fields et al. 1984a). Thus changes in the overall composition of a diet not directly related to its mineral content may influence the outcome of a trace element deficiency.

\section{ENERGY SUPPLY AND CELL METABOLISM}

Dietary trace element deficiency can alter the intermediary metabolism of cells and their energy production. For instance $\mathrm{Cu}$ deficiency is known to decrease both liver and heart ATP concentrations (Kopp et al. 1983; Davies \& Lawrence, 1986). In descriptions of the morphological effects of $\mathrm{Cu}$ deficiency attempts have been made to relate the changes, in particular the characteristic mitochondrial enlargement, to biochemical defects (Fell, 1981, 1987). Mitochondrial lesions, possibly caused by loss of cytochrome oxidase activity, are common to several of the histological defects seen in different organs in $\mathrm{Cu}$ deficiency (Fell, 1981). However, despite the morphological changes, in early and severe $\mathrm{Cu}$ deficiency the mechanical properties of hepatic mitochondria were not changed (Lawrence et al. 1985). $\mathrm{Cu}$ deficiency caused a small increase in the percentage of docosapentaenoic acid (22:5) in mitochondrial fatty acids without altering the unsaturation index (Lawrence et al. 1985). In vitro, hepatic mitochondrial state-three respiration (in the presence of ADP) decreased in $\mathrm{Cu}$ deficiency (Davies et al. 1985). However, this could not be explained by loss of cytochrome oxidase activity which was still adequate to sustain a greater rate of oxygen consumption in the presence of an uncoupler. Mitochondrial respiration seems to be decreased by impaired adenine nucleotide translocase activity secondary to a fall in total adenine nucleotide concentration (Davies \& Lawrence, 1986).

Dietary Fe deficiency in rats resulted in reduced cytochrome concentrations in the intestine (Dallman et al. 1982) and lowered succinic dehydrogenase (EC 1.3.99.1) activity in skeletal muscle (Evans \& Mackler, 1985; Quisumbing et al. 1985) before these enzymes were affected in liver, before Fe stores were exhausted and while the degree of anaemia was still relatively mild. This is associated with a lower $\mathrm{V}_{\mathbf{0}_{\mathbf{2}} \max }$ (maximum rate of oxygen consumption) and impaired endurance of the muscles (Davies et al. 1984; Evans \& Mackler, 1985). Cross-transfusion of blood between deficient and control rats to equalize haemoglobin concentrations reversed the defect in maximum $\mathrm{O}_{2}$ consumption, but the restricted endurance of muscle was not improved (Davies et al. 1984).

Before Se deficiency causes any obvious clinical changes in an animal, several biochemical defects can be detected. In addition to those which can be related to loss of GSHPx, there are others whose origins are less clear. Pascoe et al. (1983) showed that within $1 \mathrm{~d}$ Se deficiency caused decreased intestinal, cytochrome $\mathrm{P} 450$-dependent, mixed-function oxidase ( $E C$ 1 14.14 .1$)$ activity. Other effects of Se on cell metabolism require a moreprolonged deficiency. Conversion of methionine to cysteine is impaired by Se deficiency in some strains of chickens (Bunk \& Combs, 1981; Haplin \& Baker, 1984). In mice despite no change in total exhalation of carbon dioxide there is increased ${ }^{14} \mathrm{CO}_{2}$ exhalation from $\left[1-{ }^{14}\right.$ C]- or [6-14 C]glucose (Wendel \& Otter, 1987). Otter et al. (1986) reported that after partial hepatectomy in mice there is a threefold increase in the rate of DNA synthesis in Se-deficient in comparison to Se-supplemented animals. These results were interpreted by Otter et al. (1986) as indicating that $\mathrm{Se}$ is involved at as yet unidentified sites in the control of intermediary metabolism. In addition Se deficiency can cause elevated hepatic haem 
oxygenase (EC 1.14.99.3) activity (see Burk, 1983; Combs \& Combs, 1986). Se deficiency also increases hepatic glutathione synthesis and release into the plasma and elevates plasma but not hepatic glutathione concentrations (Hill \& Burk, 1985; Hill et al. 1987). Reversal of these effects on haem and glutathione metabolism during Se repletion occurs before changes in GSHPx are measurable (Burk, 1983; Reiter \& Wendel, 1984; Hill et al. 1987). The combined evidence already described provides further support for a function(s) for Se in the control of intermediary metabolism separate from its role in GSHPx.

\section{OXIDATIVE STRESS}

Many reactions required for maintenance of normal metabolism and the production of energy in the cell produce potentially-toxic free radicals as unwanted by-products. This is especially a problem with pathways which utilize $\mathrm{O}_{2}$. Trace elements play an important role in the many systems in the cell which have evolved to deal with free radicals (Fig. 2). As discussed previously, $\mathrm{Se}$ is an essential component of glutathione peroxidase which destroys hydrogen peroxide and many organic hydroperoxides that can lead to the generation of free radicals. However this enzyme will not metabolize phospholipid hydroperoxides which occur in cell membranes (Grossman \& Wendel, 1983). A seleno-protein (Mr 23000) which can metabolize phospholipid hydroperoxides has been isolated from rat heart (Ursini et al. 1985). This protein may provide a hitherto unrecognized function of $\mathrm{Se}$ in the cell, although it could yet prove to be a subunit of GSHPx.

The vitamin $E$ status of an animal can influence the consequences of Se deficiency. Heart homogenates from Se-deficient rats when incubated with $\mathrm{Fe}^{2+}$ produced the same amount of free radicals as Se-sufficient tissue. Only in the presence of a concurrent vitamin E deficiency did Se deficiency cause increased radical formation in incubated heart homogenates (Arthur et al. 1988c). Free-radical-mediated breakdown of polyunsaturated fatty acids can result in vivo in exhalation of the hydrocarbons ethane and pentane. Injection of Se- and vitamin E-deficient rats with $\mathrm{Fe}^{2+}$ caused an increase in ethane exhalation when compared with Se- and vitamin E-supplemented control animals (Dougherty et al. 1981). In Se- and vitamin E-deficient cattle increased intake of polyunsaturated fatty acid can cause myopathy (Kennedy et al. 1987), but this will not always develop in cattle of low Se and vitamin E status (Siddons \& Mills, 1981, Arthur, 1988). Myopathies in patients undergoing total parenteral nutrition and the cardiomyopathy, Keshan Disease, endemic in humans in large areas of China are associated with low Se status and can be ameliorated by Se supplementation (Robinson \& Thomson, 1983). However, the relationship of these conditions to vitamin $\mathrm{E}$ status is unclear.

Deficiencies of $\mathrm{Cu}$ and $\mathrm{Mn}$ can decrease respectively the activity of $\mathrm{Cu}-\mathrm{Zn}$ and $\mathrm{Mn}$ containing superoxide dismutases in liver and other tissues (Paynter et al. 1979; Paynter $1980 a, b$; Paynter \& Martin 1980; Zidenberg-Cherr et al. 1983). These adverse effects on antioxidant enzymes may explain why $\mathrm{Cu}, \mathrm{Mn}$ and $\mathrm{Zn}$ deficiencies have all been shown to increase the formation of free radicals or the products of free-radical-mediated damage to polyunsaturated fatty acids in various tissue homogenates and microsomal fractions (Paynter 1980 b; Sullivan et al. 1980; Zidenberg-Cherr et al. 1983; Fields et al. 1984 b; Bray et al. 1986; Hammermueller et al. 1987). Additionally, decreased tissue ascorbic acid concentrations in $\mathrm{Cu}$ deficiency may increase susceptibility to oxidative damage (Prohaska $\&$ Cox, 1983). Alternatively, the increase in free radicals and in the breakdown products of polyunsaturated fatty acids could possibly be a secondary consequence of tissue damage caused by the trace element deficiency (Arthur et al. 1988 c). Therefore, it is important to demonstrate that these increases occur early in the deficiency as an indication that they are the cause rather than the consequence of pathological changes associated with the disease. 


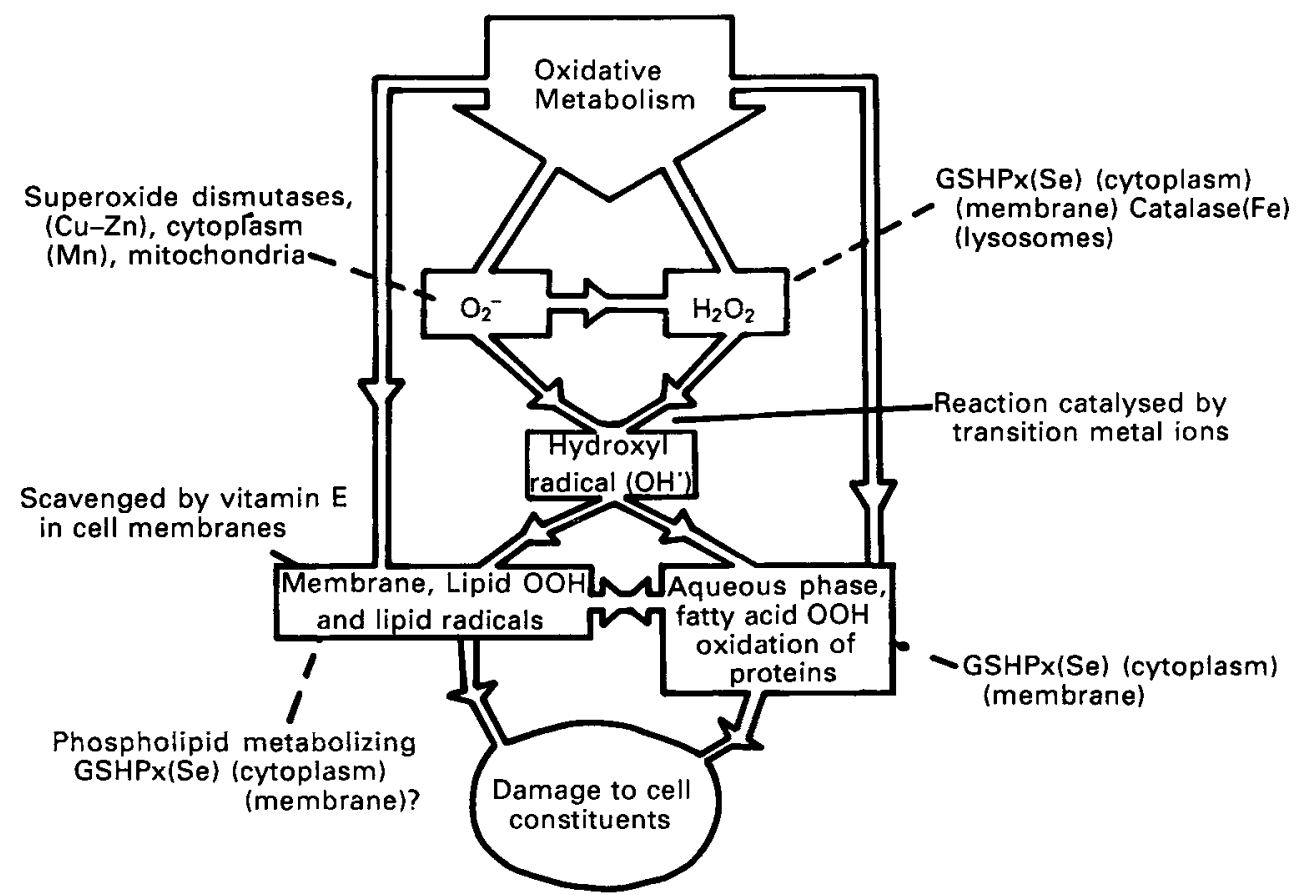

Fig. 2. Trace elements in cell antioxidant systems. Oxidative metabolism in the cell produces free radicals directly or derived from superoxide $\left(\mathrm{O}_{2}^{-}\right)$and hydrogen peroxide via a transition metal catalysed Haber-Weiss reaction. (--), Trace-element-dependant enzymes are involved in the prevention of cell damage. GSHPx, glutathione peroxidase (EC 1.11.1.9). Lipid $\mathrm{OOH}$, lipid hydroperoxides; fatty acid $\mathrm{OOH}$, fatty acid hydroperoxides. The trace element components of the different antioxidant enzymes are given in parentheses.

The demonstration in situ of increased chemiluminescence, probably due to elevated formation of oxygen derived free radicals, in liver from Se- and vitamin E-deficient rats before the occurrence of heptic necrosis has now provided strong evidence for a primary role for free radicals in the initiation of the disease (Fraga et al. 1987). However, chemiluminescence does not allow direct identification of the free radicals involved which may only be possible by using electron-spin-resonance spectroscopy.

Although trace element deficiencies generally affect cell antioxidant systems through an enzyme containing the element concerned, certain deficiencies will modify the activity of antioxidant enzymes not containing that element. Thus $\mathrm{Cu}$ deficiency can decrease the activity of the seleno-enzyme GSHPx in rat liver (Jenkinson et al. 1982; Arthur et al. 1987; Allen $e t$ al. 1988). Combined Se and vitamin E deficiencies will decrease Mn superoxide dismutase activity in rat pancreas as well as causing the expected changes in vitamin $\mathrm{E}$ concentrations and GSHPx activity (Asayama et al. 1986). Complex interactions between $\mathrm{Cu}, \mathrm{Mn}, \mathrm{Se}$ and vitamin E deficiencies have been described for the rat. These deficiencies can interact to increase the susceptibility of some tissues to peroxidation (Paynter $1980 b$ ).

\section{LIPIDS AND EICOSANOIDS}

Numerous investigators have studied the effects of $\mathrm{Zn}$ deficiency on polyunsaturated fatty acid metabolism and eicosanoid synthesis but the only consensus which appears to have emerged is that the results are very susceptible to changes caused by alterations in food 
intake (Kramer et al. 1984; Fogerty et al. 1985; Bales et al. 1986). In Zn-deficient rats ad lib. food consumption is not only reduced, but daily intakes cycle from near normal to zero and back again, presenting severe difficulties in providing suitable control animals (Williams \& Mills, 1970). Various strategies have been employed to control for these effects, but none can overcome the basic paradox that equalizing the food intake of a control rat with that of the deficient renders the former unable to grow because of inadequate intake of either protein or energy, whereas the $\mathrm{Zn}$-deficient rat has adequate supplies of both. Clearly, this is liable to produce differences in the energy and lipid metabolism of the two groups independent of any direct effects of $\mathrm{Zn}$. This is reflected in a series of investigations where there were no differences between ad lib.-fed groups regardless of their $\mathrm{Zn}$ intake, but the lipid metabolism of the groups fed ad lib. differed significantly from restricted or pairfed controls (Hwang et al. 1984; Kramer et al. 1984; Bales et al. 1986). This suggests that $\mathrm{Zn}$ deficiency per se has little effect on lipid metabolism but that the associated reduction in food intake will modify that of pair-fed controls. At present it does not seem possible to draw clear conclusions regarding the effects of $\mathrm{Zn}$ deficiency on tissue lipid composition and metabolism. For example, Fogerty et al. (1985) reviewed seven investigations of the effects of $\mathrm{Zn}$ deficiency on $\Delta 6$-desaturase activity. In three of these its activity was increased in the low-Zn animals and in the other four, reduced. Values for arachidonic acid content of liver lipids were given in four of these reports, two indicating no effect of $\mathrm{Zn}$ deficiency, one an increased concentration of this fatty acid and the fourth a decrease. Fogerty et al. (1985) suggested, however, that some of these discrepancies may reflect different effects on tissue and membrane lipids.

In contrast to the previous discussion, there does appear to be agreement that the synthesis of prostaglandins and thromboxanes is not impaired by $\mathrm{Zn}$ deficiency (Gordon et al. 1983; Hwang et al. 1984). These authors disagreed, however, on the extent to which the deficiency alters platelet aggregation. There is evidence to suggest that the numbers and affinities of prostaglandin receptors are modified by lack of $\mathrm{Zn}$ (Gordon et al. 1983; Li \& O'Dell, 1986) and it is possible that defects in platelet aggregation may result from reduced receptor sensitivity to the eiconsanoids (Li \& O'Dell, 1986).

Se has a direct role in the lipid metabolism of platelets where GSHPx converts 12hydroperoxy 5,8,11,14 eicosatetraenoic acid (12-HPETE) to the corresponding hydroxy acid, 12-HETE (Bryant et al. 1983). Products of 12-HPETE degradation as well as lipid hydroperoxides, all formed when GSHPx activity is low, can inhibit prostacyclin synthesis (Masukawa et al. 1983; Funk et al. 1987). Thus decreased prostacyclin synthesis in platelets and aorta of rats is likely to contribute to increased platelet aggregation observed in Se deficiency (Masukawa et al. 1983).

Hypercholesterolaemia is the most-widely-studied effect of $\mathrm{Cu}$ deficiency on lipid metabolism and this has been postulated to contribute to the incidence of coronary heart disease (for review, see Samman \& Roberts 1985). However marginal Cu deficiency in utero and then for a further $117 \mathrm{~d}$ caused ultrastructural damage to aorta in male rats without altering plasma or aortal cholesterol concentrations (Hunsaker et al. 1984). Possible effects of $\mathrm{Cu}$ deficiency contributing to coronary heart disease are thus not confined to changes in cholesterol metabolism.

\section{GROWTH AND CELL REPLICATION}

The most-consistent early effect of $\mathrm{Zn}$ deficiency in rats is a reduction in growth which is generally associated with a fall in voluntary food intake sufficient to produce a comparable growth check in $\mathrm{Zn}$-adequate rats given similar amounts of food (Chesters \& Quarterman, 1970). However, previous investigations had indicated and recent results confirm that 
force-feeding normal quantities of the deficient diet, far from reinstating growth, actually results in a rapid decline in the health of the rats (Chesters \& Quarterman, 1970; Park et al. 1985). Furthermore, McClain et al. (1985) have shown that administration of agents which normally stimulate food intake failed to overcome the effects of $\mathrm{Zn}$ deficiency. Also alterations in brain noradrenaline concentrations (Kasarskis et al. 1986) and plasma amino acid patterns (Wallwork et al. 1981) seen in $\mathrm{Zn}$-deficient rats appeared to result from changes in food intake rather than initiating these changes. It thus appears that failure of growth in $\mathrm{Zn}$-deficient rats results from a biochemical defect rather than from undernutrition caused by reduced appetite.

As mentioned previously, attempts to link growth failure to loss of a specific Zn-enzyme have so far proved unsuccessful. Previous investigations indicated that protein synthesis was less sensitive to lack of $\mathrm{Zn}$ than synthesis of new cells, as indicated by thymidine incorporation (Williams \& Chesters, 1970). Although it has recently been reported that protein synthesis was impaired in a cell-free system isolated from the liver of Zn-deficient rats (Hicks \& Wallwork, 1987), carefully-controlled studies in vivo indicated that in muscle most and possibly all the reduction in protein synthesis in $\mathrm{Zn}$-deficient rats could be ascribed to decreased food intake (Giugliano \& Millward, 1987). In a separate study, there was a lower mitotic index in jejunal cells of $\mathrm{Zn}$-deficient rats but the rate of jejunal protein synthesis was not affected (Southon et al. 1985). Examination of the intestines of animals force-fed a $\mathrm{Zn}$-deficient diet indicated that they were of normal weight but reduced DNA content (Park et al. 1985). Current evidence therefore points to a critical role of $\mathrm{Zn}$ in cell replication rather than protein synthesis.

The possibility that the reduced growth of $\mathrm{Zn}$-deficient animals results from lower levels of growth hormone had been investigated, but supplementation with growth hormone did not reverse the defect (Prasad et al. 1969). Although somatomedin concentrations were lowered by $\mathrm{Zn}$ deficiency (Cossack, 1986), they were not returned to normal by administration of growth hormone (Oner et al. 1984), nor were they significantly lower than in $\mathrm{Zn}$-adequate rats whose food intake was restricted to match accurately that of the deficient animals (Bolze et al. 1987).

Normal differentiation of fetal tissues was extremely sensitive to even transient reductions in $\mathrm{Zn}$ supply (Dreosti et al. 1985) and the lining of the forestomach failed to keratinize correctly in Zn-deficient rats ( $\mathrm{Ng}$ et al. 1984). In man, Zn deficiency resulted in histological changes in the epidermis consistent with slower differentiation of the cells migrating from the basal layer (Ortega et al. 1985), a pattern also seen in the parakeratotic tissues of the buccal mucosa and oesophagus of Zn-deficient rats and rabbits (Joseph et al. 1981 ; Gerson et al. 1983). Significantly, the mitotic index of the latter tissues was elevated by the deficiency even though their $\mathrm{Zn}$ content was reduced to an even greater extent than that of the body as a whole (Gerson et al. 1983). Chen (1986) has now shown that the high mitotic index in $\mathrm{Zn}$-deficient buccal mucosa results not from delayed passage of the cells through mitosis but from a shortened $G_{1}$ phase, all other phases of the cell cycle being of normal duration. These observations support the previous suggestion that the effects of $\mathrm{Zn}$ deficiency on growth can best be explained by a need for $\mathrm{Zn}$ to facilitate the changes in genetic expression required for induction of DNA synthesis and differentiation in normal cells (Chesters, 1978). A similar conclusion has been drawn regarding the function of $\mathrm{Zn}$ in the protist, Euglena gracilis (Crossley et al. 1982).

In this context, the discovery of a class of gene-regulatory proteins containing a common structure, the ' $\mathrm{Zn}$ finger', is of great potential significance to our understanding of the effects of Zn deficiency (for review, see Klug \& Rhodes, 1987). As first characterized in the protein TFIIIA, a regulator of $5 \mathrm{~S}$ rRNA transcription, these consist of loops of amino acids which are structured by $\mathrm{Zn}$ acting as a bridge between two pairs of cysteine or histidine 
residues located one on each side of the base of the loop. TFIIIA contains possibly as many as eleven of these 'fingers' which are thought to project into the major groove of the DNA and provide the specificity for the protein's binding to the promoter sequence in the gene. Only in TFIIIA and in the bacterial protein g32P have sufficient quantities of the proteins become available to demonstrate the presence of $\mathrm{Zn}$ unequivocally, but many other regulatory proteins including several steroid receptors have been shown to have amino acid sequences consistent with the formation of ' $\mathrm{Zn}$ fingers'. With TFIIIA, $\mathrm{Zn}$ has been shown to be essential for its function in purified preparations, cell-free extracts (Hanas et al. 1983; Wingender et al. 1984; Miller et al. 1985) and recently phytohaemagglutinin-stimulated lymphocytes, but investigations with $\mathrm{Zn}$-deficient rats indicated that the restriction of $\mathrm{Zn}$ availability induced by dietary deficiency was insufficient to inhibit $5 S$ rRNA synthesis (Chesters, unpublished results). This does not, however, preclude a role for other members of this group of regulatory proteins in the restriction of growth of $\mathrm{Zn}$-deficient rats.

Another possible function for $\mathrm{Zn}$ in mediating cell division could be in the synthesis of diadenosine tetraphosphate (Bambara et al. 1985; Baril et al. 1985). This dinucloetide has been postulated to act as a second messenger of mitotic induction (Grummt et al. 1986) and its only known route of synthesis is via a $\mathrm{Zn}$-mediated modification of the action of certain amino acyl transferases (Blanquet et al. 1983).

Although Fe deficiency has been shown to reduce the mitotic index of the jejunal mucosa (Perkkio et al. 1987) and lack of Mn can inhibit both growth and glycosaminoglycan synthesis (Bolze et al. 1985), neither deficiency has yet been clearly implicated in the control of cell replication.

\section{REPRODUCTION}

Deficiencies of either $\mathrm{Zn}$ or $\mathrm{Mn}$ can cause fetal abnormalities in rats but the nature of these and their relationship to the period of deficiency differ. Poor survival and ataxia in the pups are characteristics of low $\mathrm{Mn}$ intake but only when the dams have been raised from weaning on a Mn-deficient diet (for review, see Hurley, 1981). The ataxia results from low activities of $\mathrm{Mn}$-dependent transglycosylases leading to impaired mucopolysaccharide synthesis in the developing otoliths and can be prevented by injecting the dams with Mn on day 14 of gestation. Delaying Mn treatment until day 16 improved survival but did not prevent ataxia. In contrast, a $\mathrm{Zn}$-deficient diet will still induce fetal abnormalities when offered only from d 0 of gestation onwards. Maximum sensitivity to lack of $\mathrm{Zn}$ occurs between d 6 and d 12, and Record et al. (1986) have shown that within this period, the small variations in $\mathrm{Zn}$ availability induced by high or low intake of a $\mathrm{Zn}$-deficient diet on a particular day are sufficient to determine whether the tissues differentiating on that day develop normally. Restricting the intake of a low-Zn diet reduces its teratogenic effects by inducing catabolic release of $\mathrm{Zn}$ mainly from soft tissues, but in early gestation some $\mathrm{Zn}$ may be derived from bone since low-calcium diets are effective in limiting teratogenicity (Masters et al. 1983, 1986).

Lack of $\mathrm{Zn}$ at the end of gestation results in delayed and prolonged parturition in rats (Hurley, 1981). This appears to be caused by the contractions of the uterine smooth muscles being weak, irregular and poorly synchronized (Lytton \& Bunce, 1986). Underlying these defects is a failure to achieve the transfer from progesterone to oestrogen dominance, which normally occurs at the end of parturition, even though the alterations in circulating levels of the two hormones were still unaffected by the deficiency as late as $\mathrm{d} 22$ of gestation. Since the oestrogen receptor has been shown to contain putative ' $\mathrm{Zn}$ fingers' of the type discussed previously (Klug \& Rhodes, 1987), it is tempting to suggest that the disturbances of parturition in $\mathrm{Zn}$ deficiency result from a failure to synthesize adequate quantities of these proteins to allow normal induction of oestrogen-mediated changes. 
Lack of $\mathrm{Zn}$ can also cause reproductive problems in males. In rats, failure of spermatids to transform into spermatozoa, a process requiring major changes in chromatin condensation and genetic expression, was shown to be impaired after $23 \mathrm{~d}$ on a Zn-deficient diet which resulted in an inhibition of growth within the first week (Orgebin-Crist et al. 1971). Zn deficiency in rams has been reported to cause a failure of spermatogenesis (Underwood \& Somers, 1969) and oligospermy is also characteristic of $\mathrm{Zn}$ deficiency in man where it is associated with reduced testosterone levels (Prasad, 1982).

\section{IMMUNITY}

Plasma $\mathrm{Fe}$ and $\mathrm{Zn}$ concentrations are reduced by infection or acute stress, both effects being mediated by release of interleukin-I and following similar time-courses. However, whereas the loss of $\mathrm{Zn}$ from plasma was independent of blood granulocyte numbers, the reduction in plasma Fe level depended on granulocytes, possibly through release of lactoferrin by these cells (Goldblum et al. 1987).

The fall in plasma $\mathrm{Fe}$ and $\mathrm{Zn}$ concentrations during infection may be beneficial to the animal (Chesters \& Will, 1981; Weinberg, 1984) but deficiency of either element adversely affects an animal's immune response (Fraker et al. 1986; Dallman, 1987). Lack of Fe reduces interleukin-I production (Helyar \& Sherman, 1987) and decreases the 'oxidative burst' of neutrophils, probably via lower concentrations of the Fe-enzyme myeloperoxidase (Dallman, 1986; Murakawa et al. 1987). Reduced activity of another Fe-enzyme, ribonucleotide reductase $(E C 1.17 .4 .1)$, which is required for synthesis of DNA precursors, may be responsible for depressed cell-mediated immunity observed in Fedeficient humans, but not during stimulation in vitro of lymphocytes from these patients (Dallman, 1987). Unlike most Fe enzymes, ribonucleotide reductase has a relatively-low affinity for $\mathrm{Fe}$ and its activity will be lost readily as $\mathrm{Fe}$ availability declines in vivo, but in cultures it may be reactivated by adventitious $\mathrm{Fe}$ present in the medium. Humoral immunity appears relatively little affected by either Fe or $\mathrm{Zn}$ deficiency, but the latter does inhibit the cell-mediated response possibly through loss of the $\mathrm{Zn}$-dependent peptide, thymulin, which is required for the differentiation of T-lymphocytes (Dardenne et al. 1982, 1984; Fraker et al. 1984; Mercalli et al. 1984). This view is strengthened by the observation that when $\mathrm{T}$-lymphocyte numbers were reduced by $\mathrm{Zn}$ deficiency the proportion of $\mathrm{T}$ helper cells within the population remained unaltered, suggesting a uniform effect on the differentiation of all types of T-cell (Dowd et al. 1986). Alternative suggestions that alterations in adrenalcorticoid secretion are responsible for the impaired $T$-cell function seen in $\mathrm{Zn}$ deficiency seem to have been at least partially discounted by studies in which loss of $T$-cell function occurred in advance of increase in plasma glucocorticoids and even after adrenalectomy (De Pasquale-Jardieu \& Fraker, 1980).

Investigations of the effects of dietary $\mathrm{Fe}$ and $\mathrm{Zn}$ deficiencies on response to infection have produced confusing results which may be at least partially explicable by conflicting effects of the deficiencies (Kuvibidila, 1987). Thus reduced concentrations of these elements in plasma may impair bacterial growth (Weinberg, 1984) or reduce the severity of the stress response to endotoxin (Chesters \& Will, 1981), but if they also result in a reduced immune response to invading organisms, the balance of benefit and loss to the animal would be hard to predict and could explain the variation in results observed in different experiments and with different organisms.

Both $\mathrm{Se}$ and $\mathrm{Cu}$ deficiencies can impair the candidacidal activity in vitro of neutrophils and macrophages from a variety of animal species (Serfass \& Ganther, 1975; Boyne \& Arthur, 1979, 1981, 1986a, b; Jones \& Suttle, 1981 ; Boyne et al. 1986). These changes have been attributed to the loss of antioxidant enzymes allowing toxic oxygen derived species 
produced in the phagocytic cells to cause the cells own demise (Boyne \& Arthur, 1979; Arthur et al. 1981; Jones \& Suttle, 1981; Baker \& Cohen, 1984). However impaired neutrophil function can be detected at a very-early stage of $\mathrm{Cu}$ deficiency, before falls in $\mathrm{Cu}-\mathrm{Zn}$ superoxide dismutase activity can be detected, suggesting in this case mechanisms other than loss of antioxidant activity must be involved (Arthur \& Boyne, 1985). An important factor to consider in studying the effects of trace element deficiency on neutrophil function is that restriction of food intake can decrease neutrophil microbicidal activity (Boyne \& Arthur, 1986 b). Thus trace elements can not always be claimed to have a specific function in neutrophils when impaired function is accompanied by alterations in food intake and growth.

In Se deficiency the impaired neutrophil microbiocidal activity described previously is not always observed. Thus in Se-deficient rat neutrophils which had impaired candidacidal activity compared with Se-supplemented controls, killing of ingested Salmonella typhimurium and Staphylococcus aureus was not affected (Boyne et al. 1986). The reason for this may be that killing of the bacteria placed less oxidative stress on the antioxidantdeficient neutrophil than the greater metabolic activity involved in the killing of the muchlarger yeast cells. This increased activity could have included the production of sufficient oxygen derived radicals to impair the function of the neutrophil as well as the yeast.

Apart from affecting neutrophil function $\mathrm{Cu}$ and $\mathrm{Se}$ deficiencies can impair other functions of the immune system. Even with a very-mild $\mathrm{Cu}$ deficiency there were decreased numbers of antibody-producing cells in the spleen which correlated with lowered plasma caeruloplasmin activity (Prohaska \& Lukasewycz, 1981). More recently $\mathrm{Cu}$ deficiency has been demonstrated to alter the composition of splenocyte-membrane fatty acids which may possibly explain how $\mathrm{Cu}$ deficiency can cause some of the alterations in immune response (Korte \& Prohaska, 1987). Other effects of both Se and $\mathrm{Cu}$ deficiencies on the immune system are to impair the response of lymphocytes to B- and T-cell mitogens (Lukasewycz \& Prohaska, 1983; Parnham et al. 1983; Eskew et al. 1985) and reduce antibody production and natural killer-cell activity (Koller et al. 1987).

With the many adverse effects on the immune system it is hardly surprising that a subclinical $\mathrm{Cu}$ deficiency will increase the susceptibility of mice to a Pasteurella haemolytica infection (Jones \& Suttle, 1983). However, the responses of Se-deficient rats and mice to other infections are much less clear cut. Se deficiency increased the susceptibility of mice to Candida albicans infection and of rats to S. aureus infection (Boyne \& Arthur, 1986a; Boyne et al. 1986), whereas the susceptibility of rats to $S$. typhimurium and mice to Listeria monocytogenes, Plasmodium bergii or Pseudorabies virus were decreased (Boyne et al. 1984; Murray \& Murray, 1985). One explanation for these complex responses to Se deficiency may be similar to that for either increased or decreased response to infection in Fe deficiency. The growth of some organisms may be more-severely inhibited by Se deficiency than the immune system of the host, either directly or by a change in the host-cell metabolism. Alternatively the increased susceptibility of mice to $C$. albicans infection may reflect the importance of the neutrophil in dealing with this infection (Boyne \& Arthur, $1986 a$ ).

\section{FUTURE PROSPECTS}

Although much is now known of the functions of trace elements in the metabolism of animals, there are still many aspects awaiting clarification. Some of these have been highlighted here and one which may be of wide ranging significance is the role of $\mathrm{Zn}$ in cell replication and differentiation. Important advances in this field seem likely to stem from studies of cell-free systems or cells in culture, but assessment of the relationship of such observations to defects occurring in $\mathrm{Zn}$-deficient animals must take into account the 
relative levels of free $\mathrm{Zn}$ in the different experimental situations. Earlier computer simulations (May et al. 1977) and recently direct estimation (Magneson et al. 1987) indicate that in normal animals the free $\mathrm{Zn}^{2+}$ concentration in plasma is about $2 \times 10^{-10} \mathrm{M}$. Both approaches suggest that this will vary directly with the total exchangeable $\mathrm{Zn}$, and $\mathrm{Zn}$ deficient animals may therefore have between one-third and one-tenth this concentration of free $\mathrm{Zn}^{2+}$. In the past many investigations of the effects of $\mathrm{Zn}$ in vitro or in cultures have used added concentrations as high as $10^{-3} \mathrm{M}$. While the free $\mathrm{Zn}^{2+}$ concentration will in most cases be only a small fraction of the total added, nevertheless in many instances it must have been far higher than could be expected to occur in vivo. Equally recent investigations have shown that while loss of TFIIIA function because of lack of $\mathrm{Zn}$ inhibited 5S rRNA synthesis in EDTA-treated lymphocytes, this did not occur in $\mathrm{Zn}$-deficient rats where the degree of deficiency was probably less severe (Chesters, unpublished results). In future, care must be taken with experimental design to ensure that the availability of $\mathrm{Zn}$ in vitro matches that in vivo if the results obtained are to be used to explain events happening in the whole animal.

Much has still to be discovered regarding the interactions of Se and vitamin $\mathrm{E}$ on the one hand and $\mathrm{Cu}$ and $\mathrm{Fe}$ on the other in maintaining adequate aerobic respiration without allowing excessive tissue damage by oxygen derived free radicals. For example, studies have recently revealed that plasma glutathione peroxidase is immunologically distinct from that found in liver and the cellular components of whole blood (Takahashi \& Cohen, 1986). The origin of the plasma protein and its functional significance remain to be clarified. Also in future studies of antioxidant defects associated with trace element deficiencies, care must be taken to establish that increased production of free radicals is a primary effect of the deficiency rather than a secondary consequence of tissue damage.

In addition to the elements which have already received much attention, others are now emerging as important components of an animal's metabolic pathways. Recent studies of boron have indicated that differences in intake which are probably within the normal range may influence plasma oestradiol and testosterone concentrations in post-menopausal women (Nielsen et al. 1987). Furthermore nickel is known to be a component of several enzymes (Walsh \& Orme-Johnson, 1987). Although none of these are of mammalian origin the element may well be important at least in ruminants where it is present in urease (EC 3.5.1.5) of rumen micro-organisms (Spears, 1984).

There is still a long and fascinating road to be travelled before the many roles of trace elements in mammalian metabolism are fully appreciated.

\section{REFERENCES}

Allen, K. G. D., Arthur, J. R., Morrice, P. C., Nicol, F. \& Mills, C. F. (1988). Copper deficiency and tissue glutathione concentrations in the rat. Proceedings of the Society for Experimental Biology and Medicine 187. $38-43$.

Arias, I. M., Fleischer, G., Kirsch, R., Mishkin, S. \& Gatmaintan, Z. (1976). On the structure and function of ligandin. In Glutathione: Metabolism and Function, Kroc Foundation Series vol. 6, pp. 175-188 [I. M. Arias and W. B. Jakoby, editors]. New York, Raven Press.

Arthur, J. R. (1988). Effects of selenium and vitamin E status on plasma creatine kinase activity in calves. Journal of Nutrition 118, 747-755.

Arthur, J. R. \& Boyne, R. (1985). Superoxide dismutase and glutathione peroxidase activities in neutrophils from selenium deficient and copper deficient cattle. Life Sciences 36, 1569-1575.

Arthur, J. R., Boyne, R., Hill, H. A. O. \& Okolow-Zubkowska, M. J. (1981). The production of oxygen-derived radicals by neutrophils from selenium-deficient cattle. FEBS Letters 135, 187-190.

Arthur, J. R., McPhail, D. B. \& Goodman, B. A. (1988c). Spin trapping of free radicals in homogenates of heart from selenium and vitamin E deficient rats. Free Radical Research Communications 4, 311-315.

Arthur, J. R., Morrice, P. C. \& Beckett, G. J. (1988a). Thyroid hormone concentrations in selenium deficient and selenium-sufficient cattle. Research in Veterinary Science 45, 122-123.

Arthur, J. R., Morrice, P. C., Nicol, F., Beddows, S. E., Boyd, R., Hayes, J. D. \& Beckett, G. J. (1987). The effects 
of selenium and copper deficiencies on glutathione S-transferase and glutathione peroxidase in rat liver. Biochemical Journal 248, 539-544.

Arthur, J. R., Nicol, F., Boyne, R., Allen, K. G. D., Hayes, J. D. \& Beckett, G. J. (1988b). Old and new roles for selenium. In Trace Substances in Environmental Health, vol. xxi, pp. 487-498 [D. D. Hemphill, editor] University of Missouri.

Asayama, K., Kooy, N. W. \& Burr, I. M. (1986). Effect of vitamin E deficiency and selenium deficiency on insulin secretory reserve and free radical scavenging systems in islets: decrease of islet manganese superoxide dismutase. Journal of Laboratory and Clinical Medicine 107, 459-464.

Baker, S. S. \& Cohen, H. J. (1984). Increased sensitivity to $\mathrm{H}_{2} \mathrm{O}_{2}$ in glutathione peroxidase-deficient rat granulocytes. Journal of Nutrition 114, 2003-2009.

Bales, C. W., Wang, M. C., Freeland-Graves, J. H. \& Pobocik, R. S. (1986). The effects of Zn deficiency and food restriction on $\mathrm{PGE}_{2}$ and thromboxane $\mathrm{B}_{2}$ in saliva and plasma of rats. Prostaglandins 31, 859-868.

Baly, D. L., Curry, D. L., Keen, C. L. \& Hurley, L. S. (1984). Effect of manganese on insulin secretion and carbohydrate homeostasis in rats. Journal of Nutrition 114, 1438-1446.

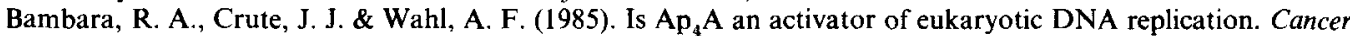
Investigation 3, $473-479$

Baril, E. P., Coughlin, S. A. \& Zamecnik, P. C. (1985). 5' $5^{\prime \prime \prime} \mathbf{P}^{1} \mathrm{P}^{4}$ diadenosine tetraphosphate (Ap 4 A): a putative initiator of DNA replication. Cancer Investigation 3, 465-471.

Beard, J., Green, W., Miller, L. \& Finch, C. (1984). Effects of Fe-deficiency anaemia on hormone levels and thermogenesis during cold exposure. American Journal of Physiology 247, R114-RII9.

Beckett, G. J., Beddows, S. E., Morrice, P. C., Nicol, F. \& Arthur, J. R. (1987). Inhibition of hepatic deiodination of thyroxine caused by selenium deficiency in rats. Biochemical Journal 248, 443-447.

Blanquet, S., Plateau, P. \& Brevet, A. (1983). The role of $\mathrm{Zn}$ in 5',5' diadenosine tetraphosphate production by aminoacyl-tRNA synthetases. Molecular and Cellular Biochemistry 52, 3-11.

Bolze, M. S., Reeves, R. D., Lindbeck, F. E. \& Elders, M. J. (1987). Influence of zinc on growth, somatomedin, and glycosaminoglycan metabolism in rats. American Journal of Physiology 252, E21-E26.

Bolze, M. S., Reeves, R. D., Lindbeck, F. E., Kemp, S. F. \& Elders, M. J. (1985). Influence of Mn on growth, somatomedin and glycosaminoglycan metabolism. Journal of Nutrition 115, 352-358.

Boyne, R. \& Arthur, J. R. (1979). Alterations in neutrophil function in selenium-deficient cattle. Journal of Comparative Pathology 89, 151-158.

Boyne, R. \& Arthur, J. R. (1981). Effect of selenium and copper deficiency on neutrophil function in cattle. Journal of Comparative Pathology 91, 271-276.

Boyne, R. \& Arthur, J. R. (1986a). The response of selenium deficient mice to Candida albicans infection. Journal of Nutrition 116, 816-822.

Boyne, R. \& Arthur, J. R. (1986b). Effects of molybdenum or iron induced copper deficiency on the viability and function of neutrophils from cattle. Research in Veterinary Science 41, 417-419.

Boyne, R., Arthur, J. R. \& Wilson, A. B. (1986). An in vivo and in vitro study of selenium deficiency and infection in rats. Journal of Comparative Pathology 96, 379-386.

Boyne, R., Mann, S. O. \& Arthur, J. R. (1984). Effect of Salmonella typhimurium infection on selenium-deficient rats. Microbios Letters 27, 83-87.

Bray, T. M., Kubow, S. \& Bettger, W. J. (1986). Effect of dietary $\mathrm{Zn}$ on endogenous free radical production in rat lung microsomes. Journal of Nutrition 116, 1054-1060.

Bremner, I., Morrison, J. N., Wood, A. M. \& Arthur, J. R. (1987). Effects of changes in dietary zinc, copper and selenium supply and of endotoxin administration on metallothionein-I concentrations in blood cells and urine in the rat. Journal of Nutrition 117, 1595-1602.

Bryant, R. W., Simon, T. C. \& Bailey, J. M. (1983). Hydroperoxy fatty acid formation in selenium deficient rat platelets: coupling of glutathione peroxidase to the lipoxygenase pathway. Biochemical and Biophysical Research Communications 117, 183-189.

Bunk, M. J. \& Combs, G. F. (1981). Evidence for impaired conversion of methionine to cysteine in the seleniumdeficient chick. Proceedings of the Society for Experimental Biology and Medicine 167, 87-93.

Burk, R. F. (1983). Biological activity of selenium. Annual Review of Nutrition 3, 53-70.

Burk, R. F. \& Gregory, P. E. (1982). Some characteristics of ${ }^{75}$ Se-P a selenoprotein found in rat liver and plasma, and comparison of it with selenoglutathione peroxidase. Archives of Biochemistry and Biophysics 213, 73-80.

Chambers, I., Frampton, J., Goldfarb, P., Affara, N., Bain, W. \& Harrison, P. R. (1986). The structure of the mouse glutathione peroxidase gene: the selenocysteine in the active site is encoded by the termination codon, TGA. EMBO Journal 5, 1221-1227.

Chen, S.-Y. (1986). Autoradiographic study of cell proliferation in acanthotic buccal epithelium of Zn-deficient rabbits. Archives of Oral Biology 31, 535-539.

Chesters, J. K. (1978). Biochemical functions of zinc in animals. World Review of Nutrition and Dietetics 32 , 135-164.

Chesters, J. K. \& Quarterman, J. (1970). Effects of zinc deficiency on food intake and feeding patterns of rats. British Journal of Nutrition 24, 1061-1069.

Chesters, J. K. \& Will, M. (1981). Measurement of zinc flux through the plasma in normal and endotoxinstressed pigs and the effects of $\mathrm{Zn}$ supplementation during stress. British Journal of Nutrition 46, 119-130. 
Combs, G. F. \& Combs, S. B. (1986). The Role of Selenium in Nutrition. New York: Academic Press Inc.

Cossack, Z. T. (1986). Somatomedin-C and zinc status in rats as affected by $\mathrm{Zn}$, protein and food intake. British Journal of Nutrition 56, 163-169.

Cowen, L. A., Bell, D. E., Hoadley, J. E. \& Cousins, R. J. (1986). Influence of dietary zinc deficiency and parenteral zinc on the rat liver fructose 1,6 bisphosphatase activity. Biochemical and Biophysical Research Communications 134, 944-950.

Crossley, L. G., Falchuk, K. H. \& Vallee, B. L. (1982). Messenger ribonucleic acid function and protein synthesis in Zn-deficient E. gracilis. Biochemistry 21, 5359-5363.

Dallman, P. R. (1986). Biochemical basis for the manifestations of Fe deficiency. Annual Review of Nutrition 6 , $13-40$.

Dallman, P. R. (1987). Iron deficiency and the immune response. American Journal of Clinical Nutrition 46, 329-334.

Dallman, P. R., Refino, C. \& Yland, M. J. (1982). Sequence of development of Fe deficiency in the rat. American Journal of Clinical Nutrition 35, 671-677.

Dardenne, M., Pleau, J.-M., Nabarra, B., Lefrancier, P., Derrien, M., Choay, J. \& Bach, J.-F. (1982). Contribution of $\mathrm{Zn}$ and other metals to the biological activity of the serum thymic factor. Proceedings of the National Academy of Sciences of the U.S.A. 79, 5370-5373.

Dardenne, M., Savino, W., Wade, S., Kaiserlian, D., Lemonnier D. \& Bach, J.-F. (1984). In vivo and in vitro studies of thymulin in marginally Zn-deficient mice. European Journal of Immunology 14, 454-458.

Davies, K. J. A., Donovan, C. M., Refino, C. J., Brooks, G. A., Packer, L. \& Dallman, P. R. (1984). Distinguishing effects of anaemia and muscle Fe deficiency on exercise bioenergetics in the rat. American Journal of Physiology 246, E535-E543.

Davies, N. T. \& Lawrence, C. B. (1986). Studies on the effects of copper deficiency on rat liver mitochondria. III. Effects on adenine nucleotide translocase. Biochimica et Biophysica Acta 848, 294-304.

Davies, N. T., Lawrence, C. B. \& Mills, C. F. (1985). Studies on the effects of copper deficiency on rat liver mitochondria II. Effects on oxidative phosphorylation. Biochimica et Biophysica Acta 809, 362-368.

De Pasquale-Jardieu, P. \& Fraker, P. J. (1980). Further characterization of the role of corticosterone in the loss of humoral immunity in the Zn-deficient $\mathrm{A} / \mathrm{J}$ mouse as determined by adrenalectomy. Journal of Immunology 124, 2650-2655.

Dougherty, J. J., Croft, W. A. \& Hoekstra, W. G. (1981). Effects of ferrous chloride and iron-dextran on lipid peroxidation in vivo in vitamin $\mathrm{E}$ and selenium adequate and deficient rats. Journal of Nutrition 111 , $1784-1796$.

Dowd, P. S., Kelleher, J. \& Guillou, P. J. (1986). T-lymphocyte subsets and interleukin-2 production in zincdeficient rats. British Journal of Nutrition 55, $59-69$.

Dreosti, I. E., Record, I. \& Manuel, S. J. (1985). Zinc deficiency and the developing embryo. Biological Trace Element Research 7, 103-122.

Eskew, M. L., Scholz, R. W., Reddy, C. C., Todhunter, D. A. \& Zarkower, A. (1985). Effects of vitamin E and selenium deficiencies on rat immune function. Immunology 54, 173-180.

Evans, T. C. \& Mackler, B. (1985). Effects of Fe deficiency on energy conservation in rat liver and skeletal muscle submitochondrial particles. Biochemical Medicine 34, 93-99.

Evenson, J. K. \& Sunde, R. A. (1988). Selenium incorporation into seleno-proteins in the Se-adequate and Sedeficient rat. Proceedings of the Society for Experimental Biology and Medicine 187, 169-180.

Fell, B. F. (1981). Pathological consequences of copper deficiency and cobalt deficiency. Philosophical Transactions of The Royal Society London 294B, 153-169.

Fell, B. F. (1987). The pathology of copper deficiency in animals. In Copper in Animals and Man, vol. 2, pp. 1-28 [J. McC. Howell and J. N. Gawthorne, editors]. Boca Raton, Florida: CRC Press.

Fell, B. F., Farmer, L. J., Farquharson, C., Bremner, I. \& Graca, D. S. (1985). Observations on the pancreas of cattle deficient in copper. Journal of Comparative Pathology 95, 573-590.

Fields, M., Ferretti, R. J., Smith, J. C. \& Reiser, S. (1984a). Effect of dietary carbohydrate and copper status on blood pressure of rats. Life Sciences 34, 763-769.

Fields, M., Ferretti, R. J., Smith, J. C. \& Reisner, S. (1984b). Interaction between dietary carbohydrate and copper nutriture on lipid peroxidation in rat tissues. Biological Trace Element Research 6, 379-391.

Fogerty, A. C., Ford, G. L., Dreosti, I. E. \& Tinsley, I. J. (1985). Zn deficiency and fatty acid composition of tissue lipids. Nutrition Reports International 32, 1009-1019.

Fraga, C. G., Arias, R. F., Llesuy, S. F., Koch, O. R. \& Boveris, A. (1987). Effect of vitamin E- and seleniumdeficiency on rat liver chemiluminescence. Biochemical Journal 242, 383-386.

Fraker, P. J., Gershwin, M. E., Good, R. A. \& Prasad, A. S. (1986). Inter-relations between $Z \mathbf{Z n}$ and immune function. Federation Proceedings 45, 1474-1479.

Fraker, P. J., Hildebrandt, K. \& Luecke, R. W. (1984). Alteration of antibody-mediated responses of suckling mice to $\mathrm{T}$-cell dependent and independent antigens by maternal marginal $\mathrm{Zn}$ deficiency, restoration of responsivity by nutritional repletion. Journal of Nutrition 114, 170-179.

Funk, C. D., Boubez, W. \& Powell, W. S. (1987). Effects of selenium-deficient diets on the production of prostaglandins and other oxygenated metabolites of arachidonic acid and linoleic acid by rat and rabbit aortae. Biochimica et Biophysica Acta 921, 213-220. 
Gerson, S. J., Meyer, J. \& Gandor, D. (1983). Decreased Zn concentration does not lead to atrophy of rat oral epithelium. Journal of Nutrition 113, 820-823.

Giugliano, R. \& Millward, D. J. (1987). The effects of severe zinc deficiency on protein turnover in muscle and thymus. British Journal of Nutrition 57, 139-155.

Goldblum, S. E., Cohen, D. A., Jay, M. \& McClain, C. J. (1987). Interleukin 1-induced depression of iron and zinc: role of granulocytes and lactoferrin. American Journal of Physiology 252, E27-E32.

Gordon, P. R., Browning, J. D. \& O’Dell, B. L. (1983). Platelet arachidonic acid metabolism and platelet function in Zn-deficient rats. Journal of Nutrition 113, 766-772.

Grossman, A. \& Wendel, A. (1983). Non-reactivity of the selenoenzyme glutathione peroxidase with enzymically hydroperoxidised phospholipids. European Journal of Biochemistry 135, 549-552.

Grummt, F., Weinmann-Dorsch, C., Schneider-Schaulies, J. \& Lux, A. (1986). Zinc as a second messenger of mitogenic induction. Experimental Cell Research 163, 191-200.

Hafeman, D. G., Sunde, R. A. \& Hoekstra, W. G. (1974). The effect of dietary selenium on erythrocyte and liver glutathione peroxidase in the rat. Journal of Nutrition 104, 580-587.

Hammermueller, J. D., Bray, T. M. \& Bettger, W. J. (1987). Effects of zinc and copper deficiencies on microsomal NADPH-dependent active oxygen generation in rat lung and liver. Journal of Nutrition 117, 894-901

Hanas, J. S., Hazuda, D. J., Bogenhagen, D. F., Wu, F. Y.-H. \& Wu, C.-W. (1983). Xenopus transcription factor A requires $\mathrm{Zn}$ for binding to the SS RNA gene. Journal of Biological Chemistry 258, 14120-14125.

Haplin, K. M. \& Baker, D. H. (1984). Selenium deficiency and trans-sulfuration in the chick. Journal of Nutrition $114,606-612$.

Helyar, L. \& Sherman, A. R. (1987). Iron deficiency and interleukin-I production by rat leukocytes. American Journal of Clinical Nutrition 46, 346-352.

Hicks, S. E. \& Wallwork, J. C. (1987). Effect of dietary Zn deficiency on protein synthesis in cell-free systems isolated from rat liver. Journal of Nutrition 117, $1234-1240$.

Hill, K. E. \& Burk, R. F. (1985). Effect of selenium deficiency on the disposition of plasma glutathione. Archives of Biochemistry and Biophysics 240, 166-171.

Hill, K. E., Burk, R. F. \& Lane, J. M. (1987). Effect of selenium depletion and repletion on plasma glutathione and glutathione dependent enzymes in the rat. Journal of Nutrition 117, 99-104.

Hunsaker, H. A., Morita, M. \& Allen, K. G. D. (1984). Marginal copper deficiency in rats. Aortal morphology and cholesterol values in first generation adult males. Atherosclerosis 51, 1-19.

Hurley, L. S. (1981). Teratogenic aspects of $\mathrm{Mn}, \mathrm{Zn} \& \mathrm{Cu}$ nutrition. Physiological Reviews 61, $249-295$.

Hwang, D. H., Chanmugan, P. \& Wheeler, C. (1984). Zinc deficiency affects neither platelet arachidonic acid nor platelet aggregation in rats. Journal of Nutrition 114, 398-403.

Jenkinson, S. G., Lawrence, R. A., Burk, R. F. \& Williams, D. M. (1982). Effects of copper deficiency on the activity of the selenoenzyme glutathione peroxidase and on excretion and tissue retention of ${ }^{75} \mathrm{SeO}_{3}{ }^{2-} . \mathrm{Journal}$ of Nutrition 112, 197-204.

Jones, D. G. \& Suttle, N. F. (1981). Some effects of copper deficiency on leucocyte function in sheep and cattle. Research in Veterinary Science 31, 151-156.

Jones, D. G. \& Suttle, N. F. (1983). The effect of copper deficiency on the resistance of mice to infection with Pasteurella haemolytica. Journal of Comparative Pathology 93, 143-149.

Joseph, C. E., Ashrafi, S. H. \& Waterhouse, J. P. (1981). Structural changes in rabbit oral epithelium caused by $\mathrm{Zn}$ deficiency. Journal of Nutrition 111, 53-57.

Kasarskis, E. J., Sparks, D. L. \& Slevin, J. T. (1986). Changes in hypothalamic noradrenergic systems during the anorexia of $\mathrm{Zn}$ deficiency. Biological Trace Element Research 9, 25-35.

Kennedy, S., Rice, D. A. \& Davidson, W. B. (1987). Experimental myopathy in vitamin E and selenium depleted calves with and without added dietary poly-unsaturated fatty acid as a model for nutritional degenerative myopathy in ruminant cattle. Research in Veterinary Science 43, 384-394.

Kirchgessner, M. \& Roth, H.-P. (1975). Estimation of metabolic availability of zinc and assessment of zinc requirements from changes in zinc-metalloenzymes. Archiv für Tierernährung 25, 83-92.

Klug, A. \& Rhodes, D. (1987). Zinc fingers: a novel protein motif for nucleic acid recognition. Trends in Biochemical Sciences 12, 464-469.

Knight, S. A. \& Sunde, R. A. (1987). The effect of progressive selenium deficiency on anti-glutathione peroxidase antibody reactive protein in rat liver. Journal of Nutrition 117, 732-738.

Koller, L. D., Mulhern, S. A., Frankel, N. C., Steven, M. G. \& Williams, J. R. (1987). Immune dysfunction in rats fed a diet deficient in copper. American Journal of Clinical Nutrition 45, 997-1006.

Kopp, S., Klevay, L. M. \& Feliksik, J. M. (1983). Physiological and metabolic characterization of a cardiomyopathy induced by chronic copper deficiency. American Journal of Physiology 245, H855-H866.

Korte, J. J. \& Prohaska, J. R. (1987). Dietary copper deficiency alters protein and lipid composition of murine lymphocyte plasma membranes. Journal of Nutrition 117, 1076-1084.

Kramer, T. R., Briske-Anderson, M., Johnson, S. B. \& Holman, R. T. (1984). Influence of reduced food intake on polyunsaturated fatty acid metabolism in Zn-deficient rats. Journal of Nutrition 114, 1224-1230.

Kuvibidila, S. (1987). Iron deficiency, cell mediated immunity and resistance to infections : present knowledge and controversies. Nutrition Research 7, 989-1003. 
Lawrence, C. B., Davies, N. T., Mills, C. F. \& Nicol, F. (1985). Studies on the effects of copper deficiency on rat liver mitochondria. I. Changes in mitochondrial composition. Biochimica et Biophysica Acta 809, 351-361.

Li, E. T. S. \& O'Dell, B. L. (1986). Effect of $\mathrm{Zn}$ status on the binding of prostaglandins to ovarian membranes and intact platelets of pregnant rats. Journal of Nutrition 116, 1448-1455.

Lukasewycz, O. A. \& Prohaska, J. R. (1983). Lymphocytes from copper-deficient mice exhibit decreased mitogen reactivity. Nutrition Research 3, 335-341.

Lytton, F. D. C. \& Bunce, G. E. (1986). Dietary zinc and parturition in the rat. 1. Uterine pressure cycles. Biological Trace Element Research 9, 151-163.

McClain, C. J., Kasarskis, E. J. \& Allen, J. J. (1985). Functional consequences of Zn deficiency. Progress in Food and Nutrition Science 9, 185-226.

Magneson, G. R., Puvathingal, J. M. \& Ray, W. J. (1987). The concentrations of free $\mathrm{Mg}^{2+}$ and free $\mathrm{Zn}^{2+}$ in equine blood plasma. Journal of Biological Chemistry 262, $1140-1148$.

Masters, D. G., Keen, C. L., Lonnerdal, B. \& Hurley, L. S. (1983). Zn deficiency teratogenicity, the protective role of maternal tissue catabolism. Journal of Nutrition 113, 905912.

Masters, D. G., Keen, C. L., Lonnerdal, B. \& Hurley, L. S. (1986). Release of zinc from maternal tissue during $\mathrm{Zn}$ deficiency or simultaneous $\mathrm{Zn}$ and $\mathrm{Ca}$ deficiency in the pregnant rat. Journal of Nutrition 116 , $2148-2154$.

Masukawa, T., Goto, J. \& Iwata, H. (1983). Impaired metabolism of arachidonate in selenium-deficient animals. Experientia 39, 405-406.

May, P. M., Linder, P. W. \& Williams, D. R. (1977). Computer simulation of metal ion equilibria in biofluids: Models for the low molecular weight distribution of $\mathrm{Ca}(\mathrm{II}), \mathrm{Mg}(\mathrm{II}), \mathrm{Mn}(\mathrm{II}), \mathrm{Fe}$ (II), $\mathrm{Cu}(\mathrm{II}), \mathrm{Zn}$ (II), and $\mathrm{Pb}$ (II) ions in human blood plasma. Journal of the Chemical Society. Dalton Transactions, 588-595.

Mercalli, M. E., Seri, S., Aquilio, E., Cramarossa, L., Del Gobbo, V., Accinni, L. \& Toniette, G. (1984). Zinc deficiency and thymus ultrastructure in rats. Nutrition Research 4, 665-671.

Miller, J., McLachlan, A. D. \& Klug, A. (1985). Repetitive zinc-binding domains in the protein transcription factor IIIA from Xenopus oocytes. EMBO Journal 4, 1609-1614.

Motsenbocker, M. A. \& Tappel, A. L. (1984). Effect of dietary selenium on plasma selenoprotein P, selenoprotein $\mathrm{P1}$ and glutathione peroxidase in the rat. Journal of Nutrition 114, 279-285.

Murkawa, H., Bland, C. E., Willis, W. T. \& Dallman, P. R. (1987). Iron deficiency and neutrophil function: different rates of correction of the depression in oxidative burst and myeloperoxidase activity after Fe treatment. Blood 69, 1464-1468.

Murray, J. M. \& Murray, A. B. (1985). The effects of selenium deficiency and repletion in the host resistance to infection. In Trace Element Metabolism in Man and Animals-5, pp. $244-247$ [C. F. Mills, I. Bremner and J. K. Chesters, editors]. Slough: CAB.

Ng, W. L., Fong, L. Y. Y., Ma, L. \& Newberne, P. M. (1984). Dietary Zn deficiency and tumorigenesis, a scanning EM study, Journal of Electron Microscopy 33, 344-348.

Nielsen, F. H., Hunt, C. D., Mullen, L. M. \& Hunt, J. R. (1987). Effect of dietary boron on mineral, estrogen and testosterone metabolism in postmenopausal women. FASEB Journal 1, 394-397.

Oner, G., Bhaumick, B. \& Bala, R. M. (1984). Effect of $\mathrm{Zn}$ deficiency on serum somatomedin levels and skeletal growth in young rats. Endocrinology 114, 1860-1863.

Orgebin-Crist, M. C., Freeman, M. \& Barney, G. H. (1971). Sperm formation in Zn-deficient rats. Annales de Biologie Animale, Biochimie, Biophysique 11, 547-558.

Ortega, S. S., Cachaza, J. A., Tovar, I. V. \& Feijoo, M. F. (1985). Zinc deficiency dermatitis in parenteral nutrition: an electron microscopic study. Dermatologica 171, 163-169.

Otter, R., Goldberg, M., Vogl, S. \& Wendel, A. (1986). Increased proliferative activity in selenium-deficient mouse liver. Chemico-Biological Interactions 52, 295-300.

Park, J. H. Y., Grandjean, C. J., Antonson, D. L. \& Vanderhoof, J. A. (1985). Effects of short-term isolated Zn deficiency on intestinal growth and activities of several brush border enzymes in weanling rats. Pediatric Research 19, 1333-1336.

Parnham, M. J., Winkelmann, J. \& Leyck, S. (1983). Macrophage, lymphocyte and chronic inflammatory responses in selenium deficient rodents. Association with decreased glutathione peroxidase activity. International Journal of Immunopharmacology 5, 455-461.

Pascoe, G. A., Sakai Wong, J., Soliven, E. \& Correia, M. A. (1983). Regulation of intestinal cytochrome P-450 and heme by dietary nutrients. Critical role of selenium. Biochemical Pharmacology 32, 3027-3035.

Paynter, D. I. $(1980 a)$. Changes in activity of the manganese superoxide dismutase enzyme in tissues of rats with changes in dietary manganese. Journal of Nutrition 110, 437-447.

Paynter, D. I. $(1980 \mathrm{~b})$. The role of dietary copper, manganese, selenium and vitamin $\mathrm{E}$ in lipid peroxidation in tissues of the rat. Biological Trace Element Research 2, 121-135.

Paynter, D. I. \& Martin, G. B. (1980). Investigations into combined dietary deficiencies of copper, selenium and vitamin E in the rat. Biological Trace Element Research 2, 175-191.

Paynter, D. I., Moir, R. J. \& Underwood, E. J. (1979). Changes in the activity of the Cu-Zn superoxide dismutase enzyme in tissues of the rat with changes in dietary copper. Journal of Nutrition 109, 1570-1576.

Perkkio, M. V., Jansson, L. T., Dallman, P. R., Siimes, M. A. \& Savilahti, E. (1987). sIgA and IgM-containing cells in the intestinal mucosa of iron-deficient rats. American Journal of Clinical Nutrition 46, 341-345. 
Peter, F. \& Wang, S. (1981). Serum iron and total iron binding capacity compared with serum ferritin in assessment of iron deficiency. Clinical Chemistry 27, 276-279.

Prasad, A. S. (ed.) (1982). Clinical and biochemical spectrum of zinc deficiency in human subjects. In Clinical, Biochemical and Nutritional Aspects of Trace Elements, pp. 3-62. New York: A. R. Liss.

Prasad, A. S., Oberleas, D., Wolff, P.\& Horwitz, J. P. (1969). Effect of growth hormone on non-hypophysectomized zinc-deficient rats and zinc on hypophysectomized rats. Journal of Laboratory and Clinical Medicine 73, 486- 494.

Prohaska, J. R. \& Cox, D. A. (1983). Decreased brain ascorbate levels in copper-deficient mice and in brindled mice. Journal of Nutrition 113, 2623-2629.

Prohaska, J. R. \& Heller, L. J. (1982). Mechanical properties of the copper-deficient rat heart. Journal of Nutrition 112, 2142-2150.

Prohaska, J. R. \& Lukasewycz, O. A. (1981). Copper deficiency suppresses the immune response in mice. Science 213, 559-561.

Quisumbing, T. L., Wong, T. M., Jen, L. S. \& Loh, T. T. (1985). Biochemical effects of mild iron deficiency and cold acclimatisation on rat skeletal muscle. Biochemical Medicine 34, 355-363.

Record, I. R., Dreosti, I. E., Tulsi, R. S. \& Manuel, S. J. (1986). Maternal metabolism and teratogenicity in Zndeficient rats. Teratology 33, 311-317.

Reeves, P. G. \& O'Dell, B. L. (1986). Effects of dietary zinc deprivation on the activity of angiotensin-converting enzyme in serum of rats and guinea pigs. Journal of Nutrition 116, 128-134.

Reiser, S., Ferretti, R. J., Fields, M. \& Smith, J. C. (1983). Role of dietary fructose in the enhancement of mortality and biochemical changes associated with copper deficiency in rats. American Journal of Clinical Nutrition 38, 214-222.

Reiter, R. \& Wendel, A. (1983). Selenium and drug metabolism-I, Multiple modulations of mouse liver enzymes. Biochemical Pharmacology 32, 3063-3067.

Reiter, R. \& Wendel, A. (1984). Selenium and drug metabolism-II, Independence of glutathione peroxidase and reversibility of hepatic enzyme modulations in deficient mice. Biochemical Pharmacology 33, 1923-1928.

Reiter, R. \& Wendel, A. (1985). Selenium and drug metabolism-III, Relation of glutathione peroxidase and other hepatic enzyme modulations to dietary supplements. Biochemical Pharmacology 34, 2287-2290.

Robinson, M. F. \& Thomson, C. D. (1983). The role of selenium in the diet. Nutrition Abstracts and Reviews 53, 3-26.

Samman, S. \& Roberts, D. C. K. (1985). Dietary copper and cholesterol metabolism. Nutrition Research 5, $1021-1034$.

Serfass, R. E. \& Ganther, H. E. (1975). Defective microbicidal killing in glutathione peroxidase-deficient rats. Nature 255, 640-641.

Siddons, R. C. \& Mills, C. F. (1981). Glutathione peroxidase activity and erythrocyte stability in calves differing in seleniur ${ }_{\iota}$ and vitamin $\mathrm{E}$ status. British Journal of Nutrition 46, 345-355.

Southon, S., Livesey, G., Gee, J. M. \& Johnson, I. T. (1985). Intestinal cell proliferation and protein synthesis in zinc-deficient rats. British Journal of Nutrition 53, 595-603.

Spears, J. W. (1984). Nickel as a 'newer trace element' in the nutrition of domestic animals. Journal of Animal Science 59, 823-835.

Sullivan, J.F., Jetton, M. M., Hahn, H. K. J. \& Burch, R. E. (1980). Enhanced lipid peroxidation in liver microsomes of Zn-deficient rats. American Journal of Clinical Nutrition 33, 51-56.

Sunde, R. A. (1984). The biochemistry of selenoproteins. Journal of the American Oil Chemists Society 61, $1891-1900$.

Sunde, R. A. \& Evenson, J. K. (1987). Serine incorporation into the selenocysteine moiety of glutathione peroxidase. Journal of Biological Chemistry 262, 933-937.

Takahashi, K. \& Cohen, H. J. (1986). Selenium-dependent glutathione peroxidase protein and activity: Immunological investigations on cellular and plasma enzymes. Blood 68, 640-645.

Takahashi, K., Newburger, P. E. \& Cohen, H. J. (1986). Glutathione peroxidase protein: Absence in selenium deficiency states and correlation with ezymatic activity. Journal of Clinical Investigation 77, 1402-1404.

Underwood, E. J. \& Somers, M. (1969). Studies of zinc nutrition in sheep. 1. The relation of zinc to growth, testicular development and spermatogenesis in young rams. Australian Journal of Agricuitural Research 20, 889-897.

Ursini, F., Maiorino, M. \& Gregolin, C. (1985). The selenoenzyme phospholipid hydroperoxide glutathione peroxidase. Biochimica et Biophysica Acta 839, 62-70.

Vallee, B. L. \& Galdes, A. (1984). The metallobiochemistry of $\mathrm{Zn}$ enzymes. Advances in Enzymology 56, $283-430$.

Wallwork, J. C., Fosmire, G. J. \& Sandstead, H. H. (1981). Effect of zinc deficiency on appetite and plasma amino acid concentrations in the rat. British Journal of Nutrition 45, 127-136.

Walsh, C. T. \& Orme-Johnson, W. H. (1987). Nickel enzymes. Biochemistry 26, 4901-4906.

Weinberg, E. D. (1984). Iron withholding: a defense against infection and neoplasia. Physiological Reviews 64, 65-102.

Wendel, A. \& Otter, R. (1987). Alterations in the intermediary metabolism of selenium-deficient mice. Biochimica et Biophysica Acta 925, 94-100. 
Williams, R. B. \& Chesters, J. K. (1970). The effects of early zinc deficiency on DNA and protein synthesis in the rat. British Journal of Nutrition 24, 1053-1059.

Williams, R. B. \& Mills, C. F. (1970). The experimental production of zinc deficiency in the rat. British Journal of Nutrition 24, 989-1003.

Wingender, E., Dilloo, D. \& Seifert, K. H. (1984). Zinc ions are differentially required for the transcription of ribosomal 5S RNA and tRNA in a HeLa cell extract. Nucleic Acid Research 12, 8971-8985.

Yang, J.-G., Morrison-Plummer, J. \& Burk, R. F. (1987). Purification and quantitation of a rat plasma selenoprotein distinet from glutathione peroxidase using monoclonal antibodies. Journal of Biological Chemistry 262, 13372-13375.

Zidenberg-Cherr, S., Keen, C. L., Lonnerdal, B. \& Hurley, L. S. (1983). Superoxide dismutase activities and lipid peroxidation in the rat: developmental correlation affected by $\mathrm{Mn}$ deficiency. Journal of Nutrition 113, 2498-2504. 